\title{
FAKTOR INTERNAL PENDORONG TERJADINYA PENGHINDARAN PAJAK PADA PERUSAHAAN SEKTOR INFRASTRUKTUR, UTILITAS, DAN TRANSPORTASI
}

\author{
Rini Handayani ${ }^{1}$, Endah Purnama Sari ${ }^{2}$, Enny Prayogo ${ }^{3}$, Elvina ${ }^{4}$ \\ 1,2,3,4 Universitas Kristen Maranatha, Bandung, Indonesia \\ Email korespondensi: ${ }^{1}$ rinie_3008@yahoo.com
}

\begin{abstract}
ABSTRAK
Peneitian ini bertujuan untuk menguji bagaimana peran ukuran perusahaan dan kepemilikan institusional mempengaruhi tax avoidance yang dimoderasi oleh variabel profitabilitas. Populasi sebagai objek riset ini menggunakan seluruh perusahaan yang listing di Bursa Efek Indonesia (BEI). Sampel yang digunakan sebagai objek penelitian diperoleh dengan menggunakan metode nonprobability sampling teknik purposive sampling yaitu perusahaan-perusahaan yang bergerak di bidang infrastructure, utilities, and transportation yang listing di BEI pada periode waktu 2014-2018. Kriteria yang ditetapkan peneliti adalah perusahaan yang tidak memenuhi kriteria yang telah ditetapkan, tidak digunakan dalam penelitian ini. Hasil penelitian ini menunjukkan bahwa ukuran perusahaan berpengaruh terhadap tax avoidance sementara kepemilikan institusional tidak berpengaruh terhadap tax avoidance. Profitabilitas terbukti dapat memperkuat pengaruh ukuran perusahaan dan kepemilikan institusional terhadap tax avoidance. Implikasi dari hasil riset ini dapat memberikan masukan dan pengetahuan bagi Perusahaan dalam mengambil keputusan dan menyelesaikan tindakan tax avoidance yang akan dan sudah dilakukan perusahaan dan bagi manajemen perusahaan dapat memikirkan strategi yang sesuai untuk mengalokasikan biaya di dalam perusahaan untuk meminimalkan tax avoidance.
\end{abstract}

Kata kunci: kepemilikan institusional; profitabilitas; ukuran perusahaan; tax avoidance

\section{ABSTRACT}

This research has the aim of seeing how the role of Company Size and Institutional Ownership affects Tax Avoidance which is moderated by the Profitability variable. The population as the object of this research uses all companies listed on the Indonesian Stock Exchange (IDX). The sample used as the research object was obtained using non-probability sampling method, purposive sampling technique, namely companies engaged in the infrastructure, utilities, and transportation sectors listed on the IDX in the 2014-2018 time period. The criteria set by the researcher are companies that do not meet the predetermined criteria, not used in this study. The results of this study indicate that company size has an effect on tax avoidance while institutional ownership has no effect on tax avoidance. Profitability is proven to strengthen the influence of company size and institutional ownership on tax avoidance. The implication of the results of this research can provide input and knowledge for the company in making decisions and resolving tax avoidance actions that the company will and have taken and for company management to think about appropriate strategies to allocate costs within the company to minimize tax avoidance.

\section{Keywords: company size; institutional ownership; profitability; tax avoidance}

\section{KETERANGAN ARTIKEL}

Riwayat Artikel: diterima: 18 Februari 2021; direvisi: 24 Maret 2021; disetujui: 3 Juni 2021

Klasifikasi JEL: H26

Cara mensitasi: Handayani, R., Sari, E. P., Prayogo, E., \& Elvina. (2021). Faktor Internal Pendorong Terjadinya Pengindaran Pajak pada Perusahaan Sektor Infrastruktur, Utilitas, dan Transportasi. JIAFE (Jurnal IImiah Akuntansi Fakultas Ekonomi), 7(1), 115-124. https://doi.org/10.34204/jiafe.v7i1.3046 
Rini Handayani: Faktor Pendorong Internal ...

\section{PENDAHULUAN}

Penerapan self assesment system di Indonesia merupakan sistem yang memberikan kepercayaan sepenuhnya kepada wajib pajak untuk melakukan perhitungan, pembayaran, serta pelaporan (Resmi, 2018). Penghitungan self assessment system memiliki dampak negatif. Dampak negatif self assessment system adalah wajib pajak akan berusaha untuk menghitung beban pajaknya serendah mungkin. Menurut Pohan (2016) manusia akan berusaha untuk melakukan tax avoidance dengan cara mengurangi bahkan berusaha tidak membayar pajak. Bagi perusahaan sebagai wajib pajak, pungutan pajak merupakan kewajiban dari pemerintah dan tidak memberikan imbalan secara langsung bagi wajib pajak.

Pada dasarnya pajak sebagai penerimaan terbesar bagi negara dengan pengelolaan yang baik akan dapat digunakan oleh negara untuk meningkatkan laju pertumbuhan dan pembangunan negara secara merata di setiap daerah. Namun, pada kenyataannya pemungutan pajak yang terjadi di Indonesia selalu mengalami penurunan karena pemerintah belum dapat mengoptimalkan pendapatan negara dari sektor pajak (Panjaitan, 2016).

Menurut Kamar Dagang Indonesia dan Industri (Kadin) Indonesia yang dikutip dari Indonesia Investments (2017), rata-rata besarnya pengeluaran yang dilakukan oleh perusahaan, sebanyak $17 \%$ pengeluaran tersebut digunakan oleh perusahaan untuk kebutuhan logistik perusahaan. Berbanding terbalik dengan negara-negara lain di Asia yang menyatakan bahwa pengeluaran perusahaan untuk kebutuhan logistik perusahaan rata-rata di bawah $10 \%$. Perbedaan mendasar inilah yang membuat para investor untuk selalu membuat analisis mendalam sebelum membuat keputusan untuk melakukan investasi di perusahaan yang ada di Indonesia. Permasalahan lain terkait logistik perusahaan yang tidak efisien dianggap dapat memperkecil kesempatan bagi para pemiliki usaha untuk memperlebar sayap bisnis mereka. Hal ini tentu saja akan mempengaruhi penerimaan negara dari segi perpajakan. Perbedaan kepentingan yang sering terjadi antara pemerintah dan manajemen juga terjadi antara fiskus sebagai pemungut pajak dengan badan usaha yang diwakili oleh manajemen sebagai pembayar pajak.

Salah satu faktor penyebab konflik kepentingan adalah sisi ukuran perusahaan. Keuntungan yang bersifat konsisten dalam menghasilkan keuntungan yang dilakukan oleh perusahaan akan berdampak bagi perusahaan untuk dapat memenuhi kewajiban yang harus dilakukan oleh perusahaan dalam membayar beban pajak kepada pemerintah. Ukuran besar kecilnya badan usaha akan berdampak terhadap keadaan struktur modal perusahaan dengan melihat bahwa pada kenyataannya semakin kecil ukuran sebuah badan usaha dapat menyebabkan tingkat pertumbuhan penjualan perusahaan akan semakin menurun sehingga perusahaan akan menekan penjualan saham perusahaan. Perusahaan berusaha untuk menjalankan usaha agar dapat menghindari tagihan pajak oleh fiskus atau yang sering disebut dengan praktik penghindaran pajak dengan upaya sebaik mungkin.

Berbagai upaya telah dilakukan pemerintah untuk meningkatkan jumlah pendapatan pajak. Upaya-upaya pemerintah ini mengalami banyak kendala salah satunya adalah tax avoidance (penghindaran pajak) (Swingly \& Sukarta, 2015). Praktik penghindaran pajak dilakukan oleh manajemen dengan menggunakan celah hukum dalam perundangan, melalui kekurangan sistem perpajakan yang berlaku di Indonesia serta memanfaatkan grey area sistem perpajakan secara legal.

Ukuran sebuah perusahaan dapat tunjukkan atau dinilai oleh harta yang dimiliki oleh badan usaha, total penjualan badan usaha, besarnya keuntungan bersih, beban pajak, dan lain-lain. Hal tersebut menyebabkan apabila semakin besar ukuran sebuah badan usaha akan memberikan kesempatan bagi badan usaha untuk melakukan praktik penghindaran pajak yang menjadi semakin tinggi (Brigham \& Houston, 2010). Tidak hanya ukuran perusahaan, kepemilikan institusional digunakan dalam penelitian ini karena struktur kepemilikan perusahaan dapat digunakan oleh perusahaan untuk mengatasi atau mengurangi permasalahan dari teori agensi yang mana setidaknya akan mendorong adanya efektivitas dari kinerja manajemen (Putri \& Putra, 2017). 
Beberapa peneliti sebelumnya menyatakan bahwa dalam hubungan sebab akibat antara ukuran perusahaan dengan tax avoidance, profitabilitas tidak dapat digunakan untuk memoderasi. Sedangkan profitabilitas dapat memoderasi secara signifikan hubungan kepemilikan institutional dengan tax avoidance. Sedangkan Munandar \& Oktaviyani (2017) menyatakan bahwa Penghindaran pajak tidak dipengaruhi oleh Pertumbuhan penjualan perusahaan dan kepemilikan institusional yang dimiliki oleh perusahaan. Sedangkan dalam pengujian pengaruh solvabilitas dan pertumbuhan penjualan terhadap penghindaran pajak, variabel profitabilitas tidak dapat digunakan sebagai variable moderasi. Namun variable profitabilitas dapat memoderasi pengaruh kepemilikan institusional terhadap penghindaran pajak.

Begitu juga penelitian yang tidak memakai profitabilitas sebagai variabel moderasi antara lain dilakukan oleh Dewinta \& Setiawan (2016), mendapatkan hasil bahwa tax avoidance dipengaruhi oleh ukuran perusahaan. Hasil senada juga terdapat pada riset yang disimpulkan oleh Handayani (2018), yang menyimpulkan bahwa variabel ukuran perusahaan berpengaruh terhadap tax avoidance secara parsial. Akan tetapi penelitian yang dilakukan oleh Permata dkk. (2018), menyimpulkan bahwa variabel tax avoidance tidak dipengaruhi oleh ukuran perusahaan

Perbedaan berbagai riset dengan penelitian sebelumnya adalah peneliti menggunakan sampel penelitian perusahaan yang bergerak di bidang infrastructure, utilities, and transportation di mana perusahaan-perusahaan di sektor ini memiliki kontribusi pajaknya sangat rendah karena diindikasikan melakukan penghindaran pajak serta waktu pengamatan yang berbeda yaitu tahun 2014-2018. Tujuan riset ini adalah untuk melihat bagaimana pengaruh ukuran perusahaan dan kepemilikan institusional terhadap tax avoidance dengan profitabilitas sebagai variabel moderasi pada perusahaan sektor infrastruktur, utilitas, dan transportasi yang listing di Bursa Efek Indonesia Periode Tahun 2014-2018.

\section{KAJIAN LITERATUR DAN PENGEMBANGAN HIPOTESIS}

\section{Tax Avoidance}

Penghindaran pajak (Tax Avoidance) adalah salah satu usaha yang dapat dilakukan oleh badan usaha untuk mengurangi hutang pajak atau beban pajak yang harus dibayar oleh badan usaha dengan cara yang legal. Penghitungan tax avoidance dalam penelitian ini menggunakan dasar perhitungan Effective Tax Rates (ETR). Tax avoidance dapat diukur dengan formula sebagai berikut.

\section{Profitabilitas}

$$
C E T R=\frac{\text { cash tax paid }}{\text { net income before } \text { tax }}(1)
$$

Return on assets (ROA) adalah salah satu ukuran yang digunakan berbagai perusahaan untuk menghitung efektivitas badan usaha atau rasio yang digunakan untuk menentukan kemampuan perusahaan dapat menggunakan aset yang dimilikinya untuk memperoleh keuntungan (Prastowo \& Juliaty dalam Nasution, 2013). Profitabilitas dapat diukur dengan formula sebagai berikut.

$$
R O A=\frac{\text { net income }}{\text { total assets }}
$$

\section{Ukuran Perusahaan, Tax Avoidance, dan Profitabilitas}

Badan usaha yang memiliki ukuran besar dianggap memiliki asset lancar yang jauh lebih banyak sehingga, semakin besar ukuran perusahaan maka nilai ETR (Effective Tax Rate) perusahaan akan berbanding terbalik yaitu akan menjadi semakin kecil, hal tersebut terjadi karena badan usaha dengan skala besar akan jauh lebih mampu menguasai dan memanfaatkan SDM yang dimiliki perusahaan untuk dapat membuat tax planning yang baik untuk mengurangi beban pajak perusahaan. 
Rini Handayani: Faktor Pendorong Internal ...

Apabila ukuran badan usaha semakin besar maka total asset yang dimilikinya akan menjadi besar juga. Dalam upaya menjalankan perencanaan pajak untuk mengurangi jumlah pajak yang dibayarkan serendah mungkin, salah satu upaya yang dapat dikerjakan oleh badan usaha dengan skala besar adalah dengan mengelola total aset yang dimiliki oleh badan usaha untuk mengurangi laba sebelum pajak dengan menggunakan beban depresiasi dan beban amortisasi yang timbul dari harga perolehan aset tersebut karena beban depresiasi dan beban amortisasi dapat menjadi pengurang laba sebelum pajak perusahaan (Permata dkk. 2018). Ukuran perusahaan dapat dihitung dengan total asset yang dimilki oleh perusahaan sehingga untuk menghitung ukuran perusahaan tersebut dapat menggunakan persamaan sebagai berikut.

$$
\text { Size }=\operatorname{Ln}(\text { Total Asset })
$$

Berdasarkan teori ukuran perusahaan di atas maka hipotesis penelitian yang digunakan oleh peneliti adalah sebagai berikut.

$\mathrm{H}_{1}$ : terdapat pengaruh ukuran perusahaan terhadap tax avoidance dengan profitabilitas sebagai variabel moderasi

\section{Kepemilikan Institusional, Tax Avoidance, dan Profitabilitas}

Kepemilikan institusional adalah kepemilikan secara bersama antara perusahaan asuransi, pemerintah, investor asing atau bank yang mana sangat penting untuk investasi yang dibuat (Oktaviyani \& Munandar, 2017). Menurut Ngadiman \& Puspitasari (2014) penghindaran pajak (tax avoidance) yang dilakukan oleh badan usaha memiliki sifat yang sangat rahasia yang dapat mengurangi transparansi yang dilakukan oleh badan usaha, oleh karena itu kepemilikan institusional berperan penting untuk selalu memperhatikan tata kelola badan usaha dengan baik. Menurut Octaviyani \& Munandar (2017) tax avoidance dapat dipengaruhi oleh Kepemilikan Institusional dengan dimoderasi oleh profitabilitas. Kepemilikan institusi diukur menggunakan formula sebagai berikut.

$$
\text { Kepemilikan institusional }=\frac{\text { total saham yang dimiliki institusi }}{\text { total saham beredar }}
$$

Berdasarkan teori kepemilikan institusional di atas maka hipotesis penelitian yang digunakan oleh peneliti adalah sebagai berikut.

\section{$\mathrm{H}_{2}$ : terdapat pengaruh kepemilikan institusional terhadap tax avoidance dengan profitabilitas sebagai variabel moderasi}

\section{Ukuran Perusahaan, Kepemilikan Institusional, Tax Avoidance, dan Profitabilitas}

Institusi harus dapat berperan penting untuk selalu mengawasi, memantau, dan mendisiplinkan badan usaha untuk tidak melakukan tindakan yang dapat merugikan badan usaha dengan kapasitas saham yang dimiliki oleh Pemilik Institusional. Selain Kepemilikan Institusional, Semakin besar Ukuran Prusahaan akan berdampak dalam upaya manajemen untuk melakukan penghindaran pajak. Berdasarkan teori Ukuran Perusahaan, Kepemilikan Institusional dan Profitabilitas di atas maka hipotesis penelitian yang digunakan oleh peneliti adalah sebagai berikut.

$\mathrm{H}_{3}$ : terdapat pengaruh ukuran perusahaan dan kepemilikan institusional terhadap tax avoidance dengan profitabilitas sebagai variabel moderasi. 


\section{METODE PENELITIAN}

Penelitian ini merupakan penelitian kuantitatif. Populasi penelitian ini adalah seluruh perusahaan bergerak dibidang Infrastructure, Utilities and Transportation yang terdaftar di Bursa Efek Indonesia pada tahun 2014-2018. Sampel dipilih menggunakan teknik purposive sampling dengan kriteria sebagai berikut: (1) perusahaan yang tidak pernah delisting pada tahun 2014-2018; (2) perusahaan menyajikan laporan keuangan menggunakan mata uang rupiah, (3) perusahaan yang menyajikan laporan keuangan dengan lengkap dari tahun 2014-2018.

Teknik pengumpulan data yang digunakan dalam penelitian ini menggunakan teknik observasi dokumentasi dengan mengambil data sekunder yang berasal dari annual report iperusahaan. Pengujian hipotesis yang digunakan oleh peneliti adalah analisis Regresi Linier Berganda dengan variable moderating. Teknik analisis dengan menggunakan Moderate Regression Analysis (MRA) dengan metode OLS (Ordinary Least Square). Persamaan regresi yang peneliti gunakan adalah sebagai berikut.

$$
Y=a+b_{1} X_{1}+b_{2} X_{2}+b_{3} X_{3}+b_{4} X_{1} X_{3}+b_{5} X_{2} X_{3}+\varepsilon
$$

Di mana $\mathrm{Y}$ adalah Tax Avoidance; a adalah konstanta ; $\mathrm{b}_{1} \mathrm{X}_{1}$ adalah Koefisien Regresi dari variabel Ukuran Perusahaan ; $b_{2} X_{2}$ adalah Koefisien Regresi dari variabel Kepemilikan Institusional ; $b_{3} x_{3}$ adalah Koefisien Regresi dari variabel Profitabilitas; $b_{4} X_{1} X_{3}$ adalah Koefisien Regresi dari variabel Ukuran Perusahaan yang dimoderasi oleh Profitabilitas; $b_{5} X_{2} X_{3}$ adalah Koefisien Regresi dari variabel Kepemilikan Institusional yang dimoderasi oleh Profitabilitas dan $\varepsilon$ adalah nilai error.

\section{HASIL DAN PEMBAHASAN}

\section{Hasil Penelitian Deskriptif}

Jumlah Sampel yang digunakan dalam riset ini setelah memenuhi kriteria yang telah ditentukan oleh peneliti adalah sebanyak 18 Perusahaan yang bergerak dibidang infrastructure, utilities, and transportation yang terdaftar di BEI tahun 2014-2018 yang memenuhi standar kriteria dan pertimbangan yang dilakukan oleh peneliti. Berdasarkan hasil analisis yang dilakukan, berikut adalah hasil uji Statistik deskriptif masing-masing variabel.

Tabel 1. Deskripsi Variabel Penelitian

\begin{tabular}{|c|c|c|c|c|c|c|}
\hline & $\mathbf{N}$ & Minimum & Maximum & Mean & $\begin{array}{c}\text { Std. } \\
\text { Deviation }\end{array}$ & Median \\
\hline Ukuran Perusahaan & 80 & 24,921 & 32,960 & 29,351 & 1,912 & 29,245 \\
\hline Kepemilikan Institusional & 80 & 0,327 & 0,989 & 0,704 & 0,181 & 0,704 \\
\hline Tax Avoidance & 80 & 0,001 & 0,491 & 0,205 & 0,129 & 0,210 \\
\hline Profitabilitas & 80 & 0,012 & 0,250 & 0,069 & 0,050 & 0,057 \\
\hline
\end{tabular}

Berdasarkan pengujian statistik deskriptif yang telah dilakukan, diperoleh sebaran data dengan Jumlah sampel yaitu sebanyak 18 Perusahaan yang bergerak di bidang infrastructure, utilities, and transportation, tetapi yang memenuhi kriteria hanya sebanyak 16 perusahaan di mana masing-masing terdiri dari 5 tahun (2014-2018) yang dapat digunakan untuk pengujian Hipotesis sehingga jumlah observasi yang digunakan oleh peneliti adalah sebanyak 80.

Variabel ukuran perusahaan memiliki nilai rata-rata sebesar 29,351 dengan nilai median yang lebih kecil yaitu sebesar 29,245 artinya rata-rata perusahaan infrastructure, utilities, and transportation 
Rini Handayani: Faktor Pendorong Internal ...

memiliki ukuran yang relative besar. Variabel Kepemilikian Institusional memiliki nilai rata-rata sebesar 0,704 dengan nilai median yang lebih kecil yaitu sebesar 0,704 artinya rata-rata kepemilikan institusional perusahaan infrastructure, utilities, and transportation relatif lebih banyak. Sedangkan variabel tax avoidance memiliki nilai rata-rata sebesar 0,205 dengan nilai median yang lebih besar yaitu sebesar 0,210 artinya perusahaan infrastructure, utilities, and transportation cenderung melakukan Penghindaran Pajak. Sedangkan nilai rata-rata variabel Profitabilitas adalah sebesar 0,069 dengan nilai median yang lebih kecil yaitu sebesar 0,057 artinya rata-rata perusahaan infrastructure, utilities, and transportation memiliki nilai return on assets yang besar, yang mengindikasikan bahwa perusahan Infrastructure, utilities, and transportation tersebut memiliki target keuangan yang besar.

\section{Uji Hipotesis}

Untuk mengetahui ada tidaknya pengaruh antar variabel independent terhadap variable dependen dalam riset ini menggunakan analisis regresi linier berganda dengan Teknik Moderate Regression Analysis (MRA) di mana terdapat dua varibel independen, yaitu ukuran perusahaan dan kepemilikan institusional sedangkan variabel dependen dalam riset ini, yaitu tax avoidance dan variabel moderasi dalam riset ini adalah profitabilitas.

Tabel 2. Hasil Uji Hipotesis

\begin{tabular}{ccc}
\hline Variabel Independen & $\begin{array}{c}\text { Unstandardized } \\
\text { Coefficient B }\end{array}$ & Sig. \\
\hline Constant & $-0,859$ & 0,001 \\
Ukuran Perusahaan & 0,034 & 0,000 \\
Kepemilikan Institusional & 0,052 & 0,513 \\
Profitabilitas & 0,291 & 0,021 \\
Uk. Perusahaan*Profitabilitas & 0,021 & 0,016 \\
Kep.Inst*Profitabilitas & 0,754 & 0,049 \\
Uk.Perusahaan\&Kep.Institusional*Profitabilitas & 0,027 & 0,021 \\
\hline
\end{tabular}

Berdasarkan Tabel 6 di atas, maka persamaan regresi linier berganda dengan Teknik Moderate Regression Analysis (MRA) adalah sebagai berikut.

$$
\begin{gathered}
Y=-0,859+0,034 U P+0,052 K I+0,291 P R F T+0,021 U P * P R F T+0,754 K I * P R F T+ \\
0,027 U P . K I * P R F T \quad(6)
\end{gathered}
$$

\section{Ukuran Perusahaan dan Tax Avoidance Dimoderasi Profitabilitas}

Berdasarkan Tabel 6 di atas terlihat bahwa nilai Sig. untuk variabel Ukuran Perusahaan adalah sebesar 0,000 menunjukkan bahwa nilai sig. $<\alpha(5 \%)$ yang dapat diartikan bahwa variable tax avoidance dipengaruhi oleh variable Ukuran Perusahaan secara parsial. Riset ini sejalan dengan hasil riset yang dilakukan oleh Fiandry \& Muid (2017) di mana semakin besar ukuran sebuah badan usaha maka akan berbanding terbalik dengan nilai tingkat effective tax rate (ETR) yang dimiliki oleh perusahaan tersebut akan menjadi semakin rendah karena badan usaha yang bergerak di bidang infrastructure, utilities, and transportation yang memiliki ukuran besar akan dianggap lebih mampu menggunakan kemampuan SDM yang dimiliki oleh perusahaan untuk menjalankan praktik tax planning untuk meminimalkan jumlah pembayaran pajak yang lebih baik. Namun pada kenyataannya perusahaan-perusahaan yang bergerak dibidang infrastructure, utilities, and transportation tidak selalu bisa menggunakan kemampuan SDM 
yang dimilikinya untuk melakukan praktik tax planning karena adanya beberapa aturan yang tidak dapat dilanggar oleh manajemen perusahaan.

Berdasarkan Tabel 6 di atas juga terlihat bahwa nilai Sig. variabel Ukuran Perusahaan yang dimoderasi oleh Profitabilitas adalah 0,016 hal ini berarti bahwa nilai sig. $<\alpha(5 \%)$ yang dapat diartikan bahwa Profitabilitas dapat memoderasi pengaruh Ukuran Perusahaan terhadap tax avoidance. Berdasarkan Tabel 6 di atas juga dapat dilihat bahwa nilai Unstandardized Coefficient $B$ variabel Ukuran Perusahaan yang dimoderasi oleh Profitabilitas adalah 0,021 menunjukkan bahwa Profitabilitas dapat memperkuat pengaruh ukuran perusahaan terhadap tax avoidance. Tindakan manajemen dalam melakukan tax avoidance tidak hanya sebatas memikirkan ukuran sebuah perusahaan namun juga dilihat dari tingkat profitabilitas perusahaan di mana profitabilitas yang merupakan salah satu indikator untuk mengukur dan menilai kinerja keuangan badan usaha dalam memperoleh laba yang besar dari usaha dalam pengelolaan asset yang dimiliki perusahaan atau sering disebut dengan perhitungan rasio return on asset (ROA).

\section{Kepemilikan Institusional dan Tax Avoidance di moderasi oleh Profitabilitas}

Berdasarkan Tabel 6 di atas terlihat bahwa nilai Sig. variabel independen Kepemilikan Institusional adalah sebesar 0,513 hal ini menunjukkan bahwa nilai sig. $>\alpha(5 \%)$ yang dapat diartikan bahwa tidak terdapat pengaruh variable kepemilikan institusional terhadap tax avoidance secara parsial. Berarti banyak atau sedikitnya jumlah kepemilikan institusional di perusahaan yang bergerak di bidang infrastructure, utilities, and transportation tidak berdampak bagi sebuah perusahaan untuk melakukan tindakan penghindaran pajak (tax avoidance).

Hasil riset ini sejalan dengan hasil riset yang dilakukan oleh Shandy \& Lukviarman (2015) yang menyimpulkan bahwa kepemilikan institusional di dalam perusahaan tidak berdampak pada praktik tax avoidance yang dilakukan oleh badan usaha. Penelitian Amelia et al. (2017) juga menyatakan hal yang sama di mana institusional ownership memiliki tugas utama untuk memastikan bahwa manajemen di dalam perusahaan akan selalu membuat keputusan untuk selalu memikirkan kesejahteraan pemegang saham institusional sehingga tugas utama pemilik institusional hanya berfokus pada manajemen laba dan tidak selalu memperhatikan dan memikirkan usaha untuk memaksimalkan penghindaran pajak yang dilakukan oleh perusahaan.

Berdasarkan Tabel 6 di atas juga dapat dilihat bahwa nilai Sig. variabel Kepemilikan Institusional yang dimoderasi oleh variabel profitabilitas adalah sebesar 0,049 menunjukkan bahwa nilai sig. $<\alpha$ (5\%) yang dapat diartikan bahwa dengan adanya variabel profitabilitas dapat memoderasi pengaruh kepemilikan institusional terhadap tax avoidance.

Berdasarkan Tabel 6 di atas juga dapat dilihat bahwa nilai Unstandardized Coefficient $B$ variabel Kepemilikan Institusional yang diproksikan dengan Profitabilitas sebagai variabel moderasi adalah 0,754 menunjukkan bahwa profitabilitas dapat memperkuat pengaruh kepemilikan institusional terhadap tax avoidance. Pemilik Institusional hanya berfokus pada manajemen laba dan tidak memfokuskan pada tindakan penghindaran pajak yang dilakukan oleh perusahaan sehingga Kepemilikan Institusional ini tidak akan berdampak bagi perusahaan untuk melakukan tindakan tax avoidance namun dengan adanya profitabilitas yang merupakan gambaran kinerja keuangan perusahaan dalam menghasilkan laba dari pengelolaan aktiva yang dikenal dengan return on asset (ROA) maka kepemilikan institusional akan berdampak bagi perusahaan untuk melakukan tindakan tax avoidance.

\section{Ukuran Perusahaan, Kepemilikan Institusional, dan Tax Avoidance di moderasi oleh Profitabilitas}

Berdasarkan Tabel 6 di atas dapat dilihat bahwa nilai sig. Variabel ukuran perusahaan dan kepemilikan institusional yang diproksikan dengan profitabilitas sebagai variabel moderasi adalah sebesar 0,021 
Rini Handayani: Faktor Pendorong Internal ...

menunjukkan bahwa nilai sig. $<\alpha(5 \%)$ yang dapat diartikan bahwa profitabilitas dapat memoderasi pengaruh ukuran perusahaan dan kepemilikan institusional terhadap tax avoidance pada perusahaan yang bergerak dibidang infrastructure, utilities and transportation.

Berdasarkan Tabel 6 di atas juga dapat dilihat bahwa nilai Unstandardized Coefficient $B$ variabel ukuran perusahaan dan kepemilikan institusional yang diproksikan dengan profitabilitas sebagai variabel moderasi adalah sebesar 0,027 menunjukkan bahwa profitabilitas dapat memperkuat pengaruh ukuran perusahaan dan kepemilikan institusional terhadap tax avoidance secara simultan.

Profitabilitas merupakan salah satu alat ukur untuk menilai kinerja keuangan sebuah perusahaan dalam menghasilkan keuntungan dari pengelolaan aseet yang dimiliki oleh perusahaan yang dikenal dengan return on asset (ROA). Penelitian yang dilakukan Dendawijaya (2003) menyatakan bahwa ROA dapat digunakan oleh perusahaan untuk mengukur kemampuan perusahaan untuk memperoleh keuntungan. Semakin besar nilai ROA, maka akan berbanding lurus dengan keuntungan yang akan diperoleh perusahaan sehingga perusahaan akan semakin mudah dalam mengelola aset perusahaan.

ROA merupakan salah satu alat ukur untuk menentukan laba bersih yang diperoleh perusahaan dari pengelolaan asset perusahaan. Semakin besar nilai ROA perusahaan, maka laba bersih perusahaan dan Profitabilitas perusahaan juga akan semakin besar. Perusahaan yang memiliki nilai profitabilitas yanag besar memiliki kesempatan yang besar bagi perusahaan untuk melakukan tindakan tax planning yang dapat mengurangi jumlah beban pajak yang harus ditanggung perusahaan (Chen et al. 2010). Penelitian yang dilakukan oleh Kurniasih \& Sari (2013) menyatakan hal yang serupa bahwa nilai ROA berpengaruh secara signifikan terhadap Tax Avoidance. Apabila nilai profitabilitas perusahaan sangat tinggi maka perusahaan akan melakukan perencanaan pajak yang baik sehingga menghasilkan nilai pajak yang maksimal, dan membuat perusahaan cenderung menurunkan Tindakan penghindaran pajak. Dengan adanya variabel Profitabilitas sebagai variabel moderasi dalam penelitian ini dapat meningkatkan/memperkuat peran variabel Ukuran Perusahaan dan Kepemilikan Institusional pada perusahaan yang bergerak dibidang Infrastructure, Utilities, and Transportation untuk melakukan perencanaan dan tindakan Tax Avoidance.

\section{KESIMPULAN}

Hasil riset ini menunjukkan bahwa tax avoidance dipengaruhi oleh ukuran perusahaan. yang berarti bahwa ukuran besar kecil nya sebuah perusahaan yang bergerak dibidang infrastructure, utilities, and transportation akan berdampak pada tindakan manajemen perusahaan untuk mengambil keputusan apakah akan melakukan tindakan tax avoidance atau tidak. Tax avoidance tidak dipengaruhi oleh Kepemilikan Institusional di dalam perusahaan yang bergerak dibidang Infrastructure, utilities, and transportation. Hal ini menunjukkan bahwa keberadaan Kepemilikan Institusional dalam perusahaan Infrastructure, utilities, and transportation hanya berfokus pada manajemen laba dan tidak memfokuskan pada praktik tax avoidance yang dilakukan oleh manajemen perusahaan sehingga keberadaan kepemilikan institusional di perusahaan tidak berperan dalam menyelesaikan dan memutuskan tindakan tax avoidance.

Profitabilitas sebagai variabel moderasi dapat memperkuat pengaruh Ukuran Perusahaan terhadap tax avoidance. Hal ini menunjukkan bahwa dalam proses pengambilan keputusan untuk melakukan atau menyelesaikan tindakan tax avoidance di perusahaan selain mempertimbangkan besar kecil nya ukuran perusahaan, manajemen perusahaan juga harus mempertimbangan profitabilitas di dalam perusahaan. Profitabilitas sebagai variabel moderasi dapat memperkuat pengaruh Kepemilikan Institusional terhadap tax avoidance. Yang berarti bahwa adanya pemahaman terkait profitabilitas dapat memperkuat manajemen dan pemilik institusional perusahaan dalam pengambilan keputusan 
untuk melakukan tindakan tax avoidance. Profitabilitas sebagai variabel moderasi dapat memperkuat pengaruh Ukuran Perusahaan dan Kepemilikan Institusional terhadap tax avoidance secara simultan.

Implikasi dari hasil riset ini dapat memberikan masukan dan pengetahuan bagi perusahaan dalam mengambil keputusan dan menyelesaikan tindakan tax avoidance yang akan dan sudah dilakukan perusahaan. Dalam melakukan tindakan tax avoidance juga harus dipikirkan untuk melihat bagaimana ukuran perusahaan saat ini dan bagaimana keadaan profitabilitas di dalam perusahaan, sehingga pemilik institusional dan manajemen dalam perusahaan dapat memikirkan strategi yang sesuai untuk mengalokasikan biaya di dalam perusahaan agar tax avoidance di dalam perusahaan dapat di minimalkan. Hal ini pun agar tidak berdampak buruk bagi perusahaan dan tindakan tax avoidance dapat diterapkan dengan lebih maksimal.

\section{REFERENSI}

Amelia, M. V., Pratomo, D., Kurnia. (2017). Pengaruh Kepemilikan Institusional dan Kepemilikan Manajerial dengan Variable Kontrol Ukuran Perusahaan dan Leverage terhadap Penghindaran Pajak. E-Proceeding Of Management, 4(2), 1510-1515.

Brigham, Eugene F. \& J.F. Houston. (2010). Dasar-Dasar Manajemen Keuangan, Edisi 11. Salemba Empat.

Chen et al. (2010). Are Family Firms More Tax Aggressive Than Non-Family Firms? Journal of Financial Economics, 95(1), 41-61. https://doi.org/10.1016/j.jfineco.2009.02.003

Dendawijaya, L. (2003). Manajemen Perbankan. Ghalia Indonesia.

Dewinta, I, A, R., \& Setiawan, P, E. (2016). Pengaruh Ukuran Perusahaan, Umur Perusahaan, Profitabilitas, Leverage, dan Pertumbuhan Penjualan Terhadap Tax Avoidance. E-Jurnal Akuntansi Universitas Udayana, 14(3), 1584-1613.

Febriati, N. (2017). Pengaruh Corporate Governance, Profitabilitas, dan Leverage terhadap Tax Avoidance. JOM Fekon, 4(1), 2705-2719.

Febrianti \& Puspita (2017). Faktor-faktor yang Memengaruhi Penghindaran Pajak pada Perusahaan Manufaktur di Bursa Efek Indonesia. Jurnal Bisnis dan Akuntansi, 19(1), 38-46. https://doi.org/10.34208/jba.v19i1.63

Handayani, R. (2018). Pengaruh Return on Assets (ROA), Leverage dan Ukuran perusahaan terhadap Tax Avoidance pada Perusahaan Perbankan yang Listing di BEI Periode Tahun 2012-2015. Jurnal Akuntansi Maranatha, 10(1), 74-84.

Indonesia Investments. (2017, Juni 23). Infrastruktur di Indonesia. Indonesia Investments. https://www.indonesia-investments.com/id/bisnis/risiko/infrastruktur/item381

Kurniasih, T., \& Maria M. R. S. (2013). Pengaruh Return on Assets, Leverage, Corporate Governance, Ukuran Perusahaan dan Kompensasi Rugi Fiskal Pada Tax Avoidance. Buletin Studi Ekonomi, 18(1), 58-66.

Munandar \& Oktaviyani (2017). Effect of Solvency, Sales Growth, and Institutional Ownership on Tax Avoidance with Profitability as Moderating Variables in Indonesian Property and Real Estate Companies. Binus Business Review, 8(3), 183-188

Nasution. (2013). Berbagai Pendekatan dalam Proses Belajar Mengajar. Bumi Aksara

Ngadiman, \& Puspitasari, C. (2014). Pengaruh Leverage, Kepemilikan Institusional, dan Ukuran Perusahaan terhadap Penghindaran Pajak (Tax Avoidance) pada Perusahaan Sektor Manufaktur yang Terdaftar di Bursa Efek Indonesia 2010-2012. Jurnal Akuntansi, 18(3), 408-421. 
Panjaitan, I. (2016). Pengaruh Leverage dan Firm Size terhadap Penghindaran Pajak (Tax Avoidance) Pada Perusahaan Property Dengan Profitabilitas Sebagai Variabel Moderating. Media Manajemen Jasa, 2(2), 89-107. https://doi.org/10.52447/mmj.v2i2.1062

Permata, A, D., Nurlaela, S., \& Masitoh W, E. (2018). Pengaruh Size, Age, Profitability, Leverage, dan Sales Growth Terhadap Tax Avoidance. Jurnal Akuntasi dan Pajak, 19(1), 10-20.

Pohan, C. A. (2016). Manajemen Perpajakan Strategi Perencanaan Pajak dan Bisnis. PT Gramedia.

Putri, V. R., \& Putra, B. I. (2017). Pengaruh Leverage, Profitability, Ukuran Perusahaan Dan Proporsi Kepemilikan Institusional Terhadap Tax Avoidance. Jurnal Ekonomi Manajemen Sumber Daya, 19(1), 1-11. 